\title{
Author Correction: MEG3 long noncoding RNA regulates the TGF- $\beta$ pathway genes through formation of RNA-DNA triplex structures
}

Tanmoy Mondal, Santhilal Subhash, Roshan Vaid, Stefan Enroth, Sireesha Uday, Björn Reinius, Sanhita Mitra, Arif Mohammed, Alva Rani James, Emily Hoberg, Aristidis Moustakas, Ulf Gyllensten, Steven J.M. Jones, Claes M. Gustafsson, Andrew H. Sims, Fredrik Westerlund, Eduardo Gorab \& Chandrasekhar Kanduri

Correction to: Nature Communications https://doi.org/10.1038/ncomms8743, published online 24 July 2015.

This article contains an error in Fig. 3g. The image in the Ctrlsh+TGF- $\beta$ ligand panel was inadvertently duplicated from the image in the MEG3sh panel. The correct version of this figure appears below as Fig. 1.

Published online: 21 November 2019

(c) (i) Open Access This article is licensed under a Creative Commons Attribution 4.0 International License, which permits use, sharing, adaptation, distribution and ry reproduction in any medium or format, as long as you give appropriate credit to the original author(s) and the source, provide a link to the Creative Commons license, and indicate if changes were made. The images or other third party material in this article are included in the article's Creative Commons license, unless indicated otherwise in a credit line to the material. If material is not included in the article's Creative Commons license and your intended use is not permitted by statutory regulation or exceeds the permitted use, you will need to obtain permission directly from the copyright holder. To view a copy of this license, visit http://creativecommons.org/licenses/by/4.0/.

(C) The Author(s) 2019 
a
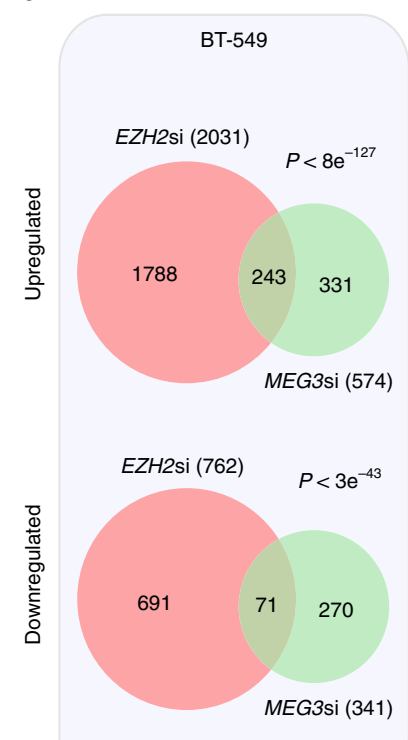

d

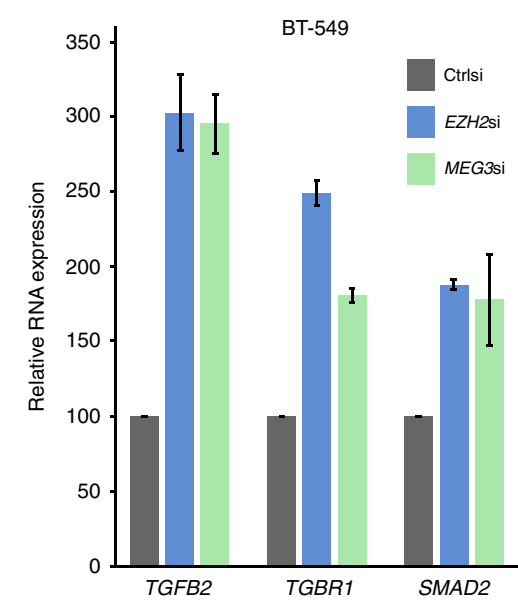

e

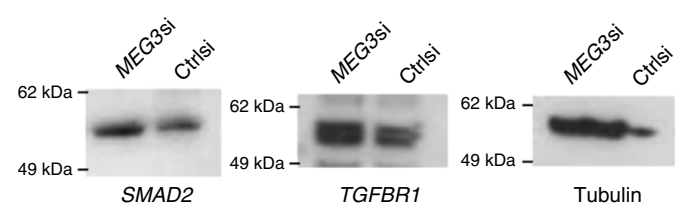

b
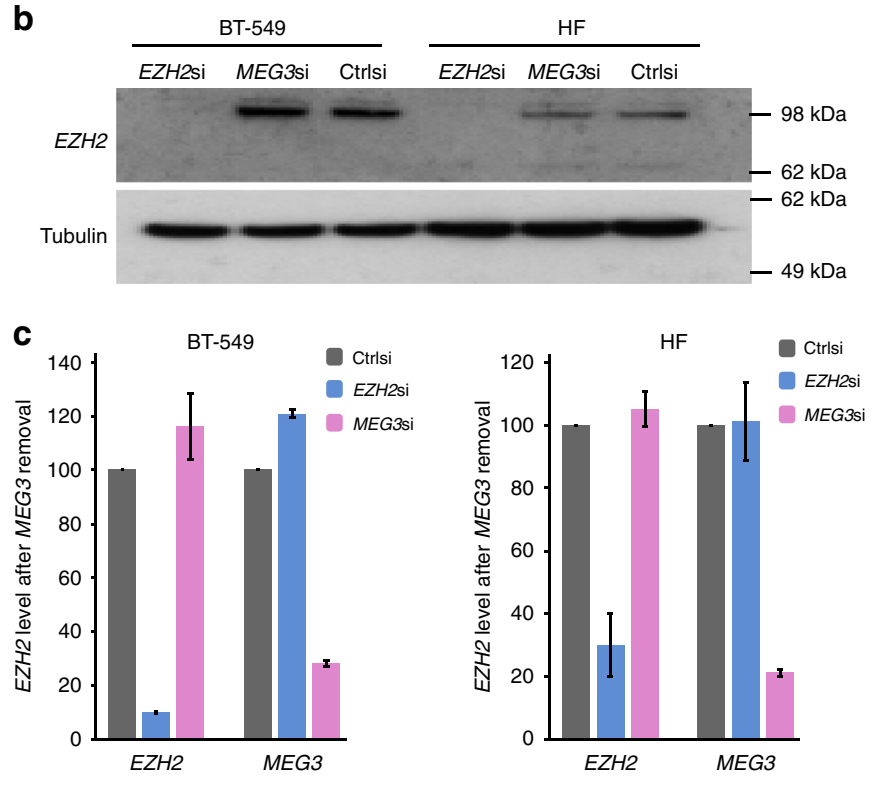

pREP4 vector

pREP4 MEG3

$\mathbf{f}$
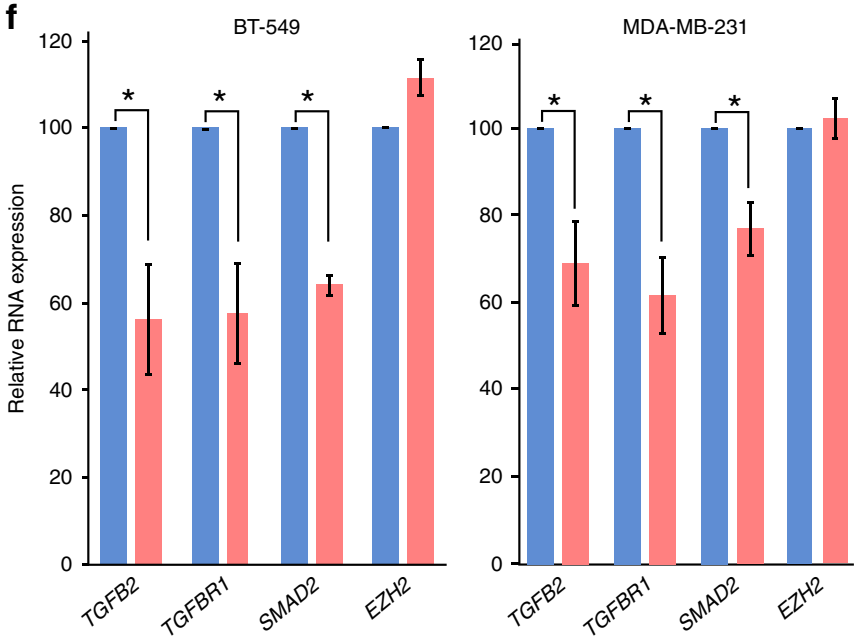

g
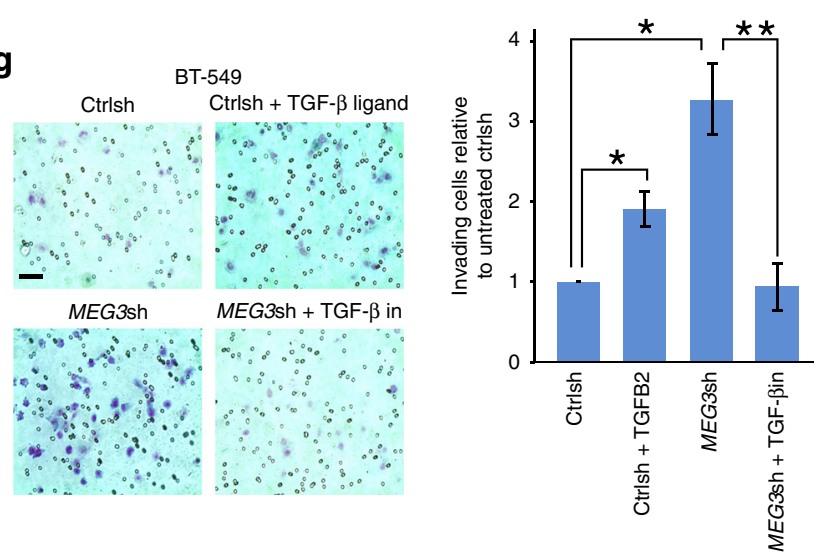

Fig. 1 